\title{
A koronavírus elleni védőoltással kapcsolatos vélekedések - az egészségügyi dolgozók szerepe az ismeretek átadásában 2020 decemberében
}

\author{
Mészáros Veronika dr. ${ }^{1}$ - Mirnics Zsuzsanna dr. ${ }^{2}$ - Kövi Zsuzsanna dr. ${ }^{1}$ \\ Arató Judit ${ }^{1}$ - Vass Zoltán dr. ${ }^{1}$ - Kiss Paszkál dr. ${ }^{3}$ - Rózsa Sándor dr. ${ }^{2}$

\footnotetext{
${ }^{1}$ Károli Gáspár Református Egyetem, Bölcsészet- és Társadalomtudományi Kar, Pszichológiai Intézet, Általános Lélektani és Módszertani Tanszék, Budapest

${ }^{2}$ Károli Gáspár Református Egyetem, Bölcsészet- és Társadalomtudományi Kar, Pszichológiai Intézet, Személyiség- és Egészségpszichológiai Tanszék, Budapest

${ }^{3}$ Károli Gáspár Református Egyetem, Bölcsészet- és Társadalomtudományi Kar, Pszichológiai Intézet, Szociálpszichológiai és Interkulturális Pszichológiai Tanszék, Budapest
}

\begin{abstract}
Bevezetés: A koronavírus elleni védőoltással kapcsolatos vélekedések igen aktuális, társadalmi szempontból fontos területét adják az egészségmagatartással foglalkozó kutatásoknak.

Célkitüzés: Vizsgálatunk a védőoltásról különbözőképpen vélekedő (oltást elutasító, oltást választó, oltáson nem gondolkodó, valamint bizonytalan) csoportok elemzését túzte ki célul az oltás előnyeinek és hátrányainak, valamint az információforrások használatának tekintetében.

Módszer: A mintát „A koronavírus-járvány okozta lelki tényezők utánkövetéses vizsgálatának” 2020 decemberében felvett adatai adják; a vizsgálat során 1009 fó válaszait egyszempontos varianciaanalízissel elemeztük.

Eredmények: Eredményeink azt mutatják, hogy a budapestiek és a Közép-Magyarországon élők, az idősebbek, a férfiak, a magasabb iskolai végzettségűek, valamint a házasok választják nagyobb eséllyel a védőoltást. Az oltásról különbözőképpen vélekedő csoportokat az oltás előnyei jobban elkülönítik egymástól, mint az oltás hátrányai. Az előnyök közül a csoportokat fóképp a társas, társadalmi érdekekre fókuszáló tételek differenciálják, melyek a járvány megfékezéséről, a fertőzés átadásáról szólnak. A használt információforrásokat elemezve pedig elmondható, hogy mind a négy csoport jobban támaszkodik a személyes (család, barátok) és az orvosi, egészségügyből érkező információkra, mint a médiából érkező hírekre.

Következtetés: Az oltási csoportok véleménye az oltás pozitív hozadékait, különösképp társadalmi hasznosságát illetően tér el, mely vélemények a leginkább a személyes kapcsolatokon, így az egészségügyi dolgozók álláspontján keresztül formálódnak. Tehát az egészségügyben dolgozóknak kiemelkedő szerepük van a hozzájuk tanácsért fordulók differenciált megértésében, szakértői tájékoztatásában és megfelelő tanácsokkal való ellátásában.
\end{abstract}

Orv Hetil. 2021; 162(24): 931-937.

Kulcsszavak: koronavírus elleni védőoltás, oltási hajlandóság, információforrások, egészségügyi dolgozók

\section{Opinions about coronavirus vaccination - the role of healthcare workers in communication in December 2020}

Introduction: Beliefs regarding coronavirus vaccination provide very actual and socially important area in mental health research.

Objective: The aim of our study was to differentiate the opinions related to coronavirus vaccination (acceptance, refusal, ignorance, hesitation). We analyzed advantages and disadvantages of vaccination, and the different channels in getting information about the vaccine.

Method: Our study is part of the "Longitudinal examination of mental factors caused by the coronavirus epidemic" research project, wave of December 2020. We analyzed the responses of 1009 people by one-way analysis of variance tests. 
Results: Our results show that elder people, males, and those who have higher education are more likely to accept the vaccine. In addition, those who live in Budapest and Cental Hungary are more likely to choose vaccination against the coronavirus than those living in other areas. The groups with different opinions on vaccination are better discriminated by benefit-related than risk-related opinions. Those benefit-related items showed the largest variance between groups, which focused on social usefulness on curbing the epidemics, preventing the spread of the infection. Analyzing the sources of information, we found that all groups rely more on personal (family, friends) and medical health information than on news from the media.

Conclusion: The opinions of the vaccination groups differ mostly regarding the positive benefits of vaccination, especially the social usefulness. Opinions are mostly formed through personal relationships including relations with healthcare workers. Healthcare professionals therefore have a key role in providing a differentiated understanding of those seeking advice, providing expert information and appropriate advice.

Keywords: coronavirus vaccination, vaccination willingness, sources of information, healthcare workers

Mészáros V, Mirnics Zs, Kövi Zs, Arató J, Vass Z, Kiss P, Rózsa S. [Opinions about coronavirus vaccination - the role of healthcare workers in communication in December 2020]. Orv Hetil. 2021; 162(24): 931-937.

(Beérkezett: 2021. április 6.; elfogadva: 2021. április 21.)

\begin{abstract}
Rövidítések
COVID-19 = (coronavirus disease 2019) koronavírus-betegség 2019; KRE-BTK = Károli Gáspár Református Egyetem Bölcsészet- és Társadalomtudományi Kar; SARS-CoV-2 = (severe acute respiratory syndrome coronavirus 2 ) súlyos akut légúti tünetegyüttest okozó koronavírus-2; $S \mathrm{SD}=$ standard deviáció; $\mathrm{WHO}=($ World Health Organization $)$ Egészségügyi Világszervezet
\end{abstract}

A COVID-19-pandémia miatt 2020. március 11-én Magyarország Kormánya rendkívüli jogrendet hirdetett. A fertőzés terjedésének megfékezése érdekében több korlátozást is bevezettek, melyekkel idôt kívántak nyerni arra, hogy az ország egészségügyi ellátórendszere felkészülhessen a járvány visszaszorítására [1], nemzetközi szinten pedig elindulhasson a vakcinafejlesztés. A járvány kitörése után rövid idővel több gyógyszercég és biotechnológiai laboratórium kezdte meg az oltóanyag fejlesztését, hiszen a védőoltás megléte kritikus pont a járvány elleni védekezésben [2].

A SARS-CoV-2 elleni vakcina egyéni és társadalmi szinten egyaránt jelentőséget hordoz [3]. Közösségi szerepe elsődlegesen abban áll, hogy bizonyos mértékú átoltottság felett a járvány újbóli hullámainak esélye jelentôs mértékben csökken, valamint a beoltottak egyáltalán nem vagy sokkal kevésbé terjesztik a fertőzést [4]. Egyéni szinten pedig az oltóanyag a leírásban meghatározott százalékban védettséget biztosít a SARS-CoV-2-variánsokkal szemben, így közvetett módon hozzájárul az egyén és a társadalom stresszterheltségének csökkentéséhez is [5].

Többek között ezen okok miatt az oltási hajlandóság felmérése már 2020 nyarán elkezdődött. Szisztematikus összehasonlító vizsgálatokból tudjuk, hogy több európai országban az oltási hajlandóság már nyáron $50 \%$ feletti arányt mutatott. A vakcinát az emberek többsége már akkor beadatta volna magának Olaszországban $(53,7 \%)$, Oroszországban $(54,9 \%)$, Lengyelországban $(56,3 \%)$ és Franciaországban $(58,9 \%)$ is $[6,7]$. Magyarországon ez az arány $59,1 \%$ a Központi Statisztikai Hivatal 2021. áprilisi felmérése alapján, amely életkorra, lakóhelyre, nemre, korra és iskolai végzettségre nézve reprezentatív volt. Az oltást ellenzók 17,5\%-os, a bizonytalanok 17,6\%-os, illetve akik még nem foglalkoztak a témával, $5,8 \%$-os arányban voltak jelen a vizsgálatban [8]. A demográfiai tényezóket tekintve pedig a legidősebbek kérik a legnagyobb, a legfiatalabbak pedig a legkisebb arányban az oltást. A férfiak és a magasabb iskolai végzettségúek szintén kihasználják az oltás adta lehetőségeket. A közvéleménykutatók pedig egyetértenek abban, hogy lakóhely szerint a budapestiek közül kérik a legtöbben, az északmagyarországi régióban élók közül pedig a legkevesebben a vakcinát $[8-10]$.

Arról, hogy megmondjuk, milyen okokból ellenzik az emberek a védőoltást, jóval több információ áll rendelkezésünkre, mint arról, hogy miért szeretnék azt beadatni maguknak. Nemzetközi felmérésből tudjuk, hogy a megkérdezett európaiak 55\%-a elsősorban attól tart, hogy a vakcina nem biztonságos, mellékhatásai rövid, illetve hosszú távon károsítják az egészséget [3]. Körülbelül ez az arány figyelhetó meg hazánkban is. Az emberek $58 \%$-a nem tartja biztonságosnak az oltást, $45 \%$ érzi úgy, hogy nem áll rendelkezésére elég információ, 39\% nyilatkozik arról, hogy nincs elég ismerete a vakcináról, és 33\% nem bízik a gyártóban. Emellett az oltást ellenzők negyede nem hisz a vírus létezésében, terjedésében sem [9]. Az előzetes vizsgálatok alapján tehát többet tudhatunk meg arról, hogy az emberek miért ellenzik a vakcinát, az előnyök és a hátrányok együttes elemzése azonban differenciáltabb képet festhet. Jelen tanulmányunk első célkitűzéseként az oltással kapcsolatos állásfoglalásokat a védőoltás előnyei, illetve hátrányai mentén elemezzük. 
Emellett arra is vállalkozunk, hogy feltérképezzük azokat az információs csatornákat, melyeken keresztül az emberek hozzájutnak az oltással kapcsolatos tudáshoz. Nemzetközi összehasonlító elemzésekből tudjuk, hogy a koronavírus-járvány elején Hollandiában, Németországban és Olaszországban a televízió és a közösségi média nagy szerepet játszott [7]. A saját - a nemre, az életkorra és a legmagasabb iskolai végzettségre is vonatkozó - kutatásunkból pedig azt is látjuk, hogy kezdetben a legtöbb ember internetes hírportálokról tájékozódott, és ezt tekintették a legmegbízhatóbb információforrásnak. Emellett az ismeretszerzésben helyet kapott a kormányzati tájékoztatás és a családon belül történő informálás is [11]. Mivel az információszerzés módja krízisszituációban rövid időn belül is jelentősen változhat, a jelen vizsgálatunkban, 2020 decemberében egy specifikusabb kérdést tettünk fel vizsgálati személyeinknek. A járvány helyett az oltással kapcsolatos információszerzésre kérdeztünk rá. Tanulmányunkban ennek a kérdésnek az elemzésére is fókuszálunk.

\section{Módszer}

A vizsgálati mintát a Károli Gáspár Református Egyetem „A koronavírus-járvány okozta lelki tényezők utánkövetéses vizsgálata" adta. A longitudinális vizsgálatba 2020 áprilisában kvótás (nemre, életkorra és iskolai végzettségre reprezentatív) mintavétellel több mint 2000, 18 év feletti magyar állampolgárságú személy került be. A jelen tanulmányban a vizsgálat harmadik időpontjában, a 2020 decemberében felvett adatokat elemeztük, 1009 fó válaszát. Kérdőíveinket ebben az időpontban döntően nők (633 fó, 62,74\%) töltötték ki. Résztvevőink többsége Közép-Magyarországon él (583 fó, 57,78\%), a minta fennmaradó része a Dunántúlon (209 fó, 20,71\%), az Alföldön (149 fó, 14,77\%), valamint Észak-Magyarországon (68 fó, 6,74\%), így a minta reprezentativitása ebben az időpontban sérült. A legtöbben felsőfokú végzettségúek (461 fó, 45,69\%), de jelentős számban képviseltetik magukat a középiskolai végzettségüek is (364 fö, 36,08\%). Mintánk átlagéletkora 44,66 év (SD = 18,37 év). A résztvevők válaszoltak arra a kérdésre is, hogy döntöttek-e már arról, hogy beadatják maguknak a koronavírus elleni védőoltást. Önmagukat négyféleképp kategorizálhatták: „még nem gondolkodott az oltáson” (114 fö, 11,30\%) „,bizonytalan az oltás beadatásával kapcsolatban” (380 fó, 37,65\%), „beadatná magának a védőoltást” (241 fó, 23,89\%), és „ellenzi az oltás beadatását” (274 fó, 27,16\%). A továbbiakban e négy csoport mentén végeztünk elemzéseket.

Adataink alapján elmondható, hogy azok között, akik még nem gondolkodtak a védőoltáson, az oltást választókhoz képest nagyobb arányban vannak fiatalok (18-34 év; a csoporton belül $41,1 \%)$, alacsony iskolai végzettségüek (8 általános és középiskola; 50\%), valamint az észak-alföldi régióban élők (13,6\%). Hasonló arányok mondhatók el az oltást ellenzó csoportról is: az oltást választókhoz képest sokkal többen vannak köztük fiatalok (18-34 év; 44,2\%) és maximum középiskolai végzettségüek (65,3\%). Emellett kiemelkedő ebben a csoportban a nők aránya is (70,2\%). A bizonytalan és az oltást választó csoport a szociodemográfiai karakterében hasonló. Az oltást ellenzőkhöz képest inkább az idősebb korosztály tagjai vannak ezekben a csoportokban (55-99 év; rendre 33,4\% és 47,6\%); az oltást ellenző és a védőoltáson nem gondolkodókhoz képest ezekben a csoportokban jóval több a magasabb iskolai végzettségü (fóiskolai vagy egyetemi diplomával rendelkező; rendre 49,3\% és 66,7\%), a házas ember (rendre $51,1 \%$ és $52,5 \%$ ) és a krónikus beteg (rendre 37,9\% és 46,8\%). Továbbá jelentôs az is, hogy az oltást választók között a többi csoporthoz képest a legmagasabb a fóvárosban élők (51,4\%), az 55-99 évesek $(33,8 \%)$ és a krónikus betegek $(46,8 \%)$ aránya.

Tanulmányunkban elsőként a védőoltásról különbözőképpen vélekedő csoportok oltással kapcsolatos véleményét vizsgáltuk. Ennek elemzésére a nemzetközi szakirodalomban leírtak alapján kérdőívet állítottunk össze, és a jelenlegi helyzethez igazítottuk $[12,13]$. A kérdés a következő volt: „Az alábbiakban a koronavírus-védőoltással kapcsolatosan fogalmazunk meg állításokat. Kérjük, értékelje, hogy mennyire ért egyet ezekkel.” Az instrukcióra ötfokú skálán érkeztek válaszok, amelyeknél az 1 „egyáltalán nem értek egyet”, míg az 5 „teljesen egyetértek” jelentésü volt. A kérdőív pozitív és negatív állításokat tartalmaz, a továbbiakban ezeket előnyöknek és hátrányoknak nevezzük. Az előnyök között olyan tételek találhatók, mint hogy a védőoltás megóvja az egészséget, hatékony a járvány megfékezésére, vagy a róla kapott információk megfelelők. A hátrányok közé például olyan állítások kerültek, miszerint a gyógyszergyártó cégek gyakran elfedik a vakcinák mellékhatásait, vagy hogy az oltás mellékhatásai felülmúlják annak előnyeit. A két skálát külön elemezve mutatjuk be a négy oltási csoport eredményeit. A védőoltással kapcsolatos állítások mellett fontosnak gondoltuk annak elemzését is, hogy a résztvevôk honnan szerzik be a COVID-dal kapcsolatos információkat. Az 'ismeretek' kérdőív eredeti forrása Charron, Gautier és Jestin [14] tanulmánya volt, melynek alapján saját kérdőívünkben kilenc információforrást jelöltünk meg. A „Honnan szerzi ismereteit a védőoltással kapcsolatosan?" kérdésre a válaszadás ötfokú skálán történt, amelyen az 1 „semennyire” az 5 pedig „teljes mértékben” jelentésû volt. A könnyebb áttekintés érdekében a kilenc forrást elméleti megfontolásokra és empirikus eredményekre (faktorelemzés) támaszkodva a következő csoportokba rendeztük: hagyományos média (újság, TV, rádió), internetes média (internetes hírportál, közösségi média és www.koronavirus.gov.hu), család és barátok, valamint a családorvos vagy más egészségügyi dolgozók. „A koronavírus-járvány okozta lelki tényezők utánkövetéses vizsgálatát” a KRE-BTK Pszichológiai Intézetének Kutatásetikai Bizottsága engedélyezte a 26/2020/P / ET/3 etikai engedélyszámon. Az adatgyújtés 2020 decemberében, a második hullám kezdete után történt, 
a hatályos jogszabályok figyelembevételével, döntően online $(91 \%)$, kisebb részben - az idősebb, illetve internet-hozzáféréssel nem rendelkező kitöltők esetében - pedig telefonos lekérdezéssel. A vizsgálat elemzéseit SPSS 27 -es programcsomaggal (IBM Corporation, Armonk, NY, Egyesült Államok) és egyszempontos varianciaanalízissel (Bonferroni-utóelemzéssel) végeztük, melynek szignifikanciaszintjét $\mathrm{p} \leq 0,05$ értékben határoztuk meg.

\section{Eredmények}

Elsóként a mintánk oltással kapcsolatos véleményét elemeztük. Az oltás előnyeinek és hátrányainak skálája azt mutatta, hogy az oltási csoportok sokkal jobban megkülönböztethető́k a védőoltás előnyei, mint a hátrányai mentén. Míg az előnyök a variancia $52 \%$-át $\left(\eta^{2}=0,52\right)$, addig a hátrányok a $28 \%$-át $\left(\eta^{2}=0,28\right)$ magyarázták, így az oltást választó és az oltást ellenző csoportot is markánsabban differenciálta a vakcina pozitív hozadéka. Az előnyök esetében az oltást választók többsége csaknem az összes előnnyel „egyetértett” (a csoport átlaga $=3,91$; $\mathrm{SD}=0,63), \mathrm{az}$ oltást ellenzők viszont „nem értettek egyet" (átlag $=2,25 ; \mathrm{SD}=0,75$ ). A hátrányok megítélése során az oltást választókon kívül a többi csoport átlagértéke a 3-as érték körül mozgott, ami azt jelzi, hogy a legtöbb esetben bizonytalan választ adtak. Így az elönyök esetében határozottabb állásfoglalás volt megfigyelhető a csoportokban. A csoportok közötti legnagyobb átlagkülönbségek azokban a tételekben voltak, melyek arra kérdeztek rá, hogy a védőoltás hatékony-e a járvány megfékezésében, illetve megakadályozza-e a fertőzés átadását más embereknek: (rendre $\mathrm{F}[3,975]=$ $196,00[\mathrm{p}=0,000] ; \eta^{2}=0,38$; és $\mathrm{F}[3,975]=164,92$ $\left.[\mathrm{p}=0,000] ; \eta^{2}=0,34\right)$. A jelentôsebb különbség itt abból adódott, hogy az oltást választók ezekkel a tételekkel nagyobb mértékben értettek egyet a többi csoporthoz képest, tehát esetükben kifejezettebb volt a másokra (társadalom egészére) irányuló figyelem (1. ábra).

A négyféle oltási csoport között különbség volt a tekintetben is, hogy milyen gyakran használták a különbözô információforrásokat. Âm a védőoltással kapcsolatos véleménykülönbségek az információhasználat varianciájának mindössze 2-8\%-át $\left(\eta^{2}=0,2-0,8\right)$ magyarázták, így a csoportok közötti különbség kismértékuu. Kiemelendő eredmény azonban, hogy a személyes információk (család, barátok, háziorvos és egészségügyi személyzet) mindegyik csoport számára fontosabbak voltak, mint a média által kínált hírek. Még az oltást ellenző csoport esetén is jelentősebbek a személyes és a szakértői kötelékek, tehát az egészségügyi személyzet kommunikációjának minden esetben szerepe van (2. ábra).

\section{Megbeszélés}

A koronavírus-járványra országunk igen határozott, szigorú intézkedéseket hozott 2020. március 1l-én ugyanazon a napon, amikor a WHO világjárvánnyá nyil- vánította a fertózést [1]. A határozott intézkedések hatására a magyarok többségének nyilvánvalóvá vált, hogy súlyos fertőzéssel állunk szemben. A nemre, korra és a legmagasabb iskolai végzettségre reprezentatív felmérésünk azt mutatta, hogy 2020 áprilisának elején a lakosság 71\%-a súlyosnak vagy nagyon súlyosnak értékelte a vírus általi fenyegetettséget [11].

Az idő előrehaladtával az emberek álláspontja differenciálódott a járvánnyal kapcsolatosan. Míg 2020 áprilisában elsősorban internetes hírportálokról és a televízióból tájékozódtak [11], a késóbbiekben egyre nagyobb szerepe lett a családnak, a barátoknak, az orvosoknak és az egészségügyi személyzetnek is. Eredményeink alapján a szoros társas közeg és az egészségügyi dolgozók megbízható információforrást jelentenek a járvány vonatkozásában. Az egészségügyi dolgozók mindenféle, a védőoltással kapcsolatos vélekedés formálásában részt vesznek, ami mutatja az orvostársadalom szavának kiemelkedő szerepét. Társadalmi szempontból jelentősnek és előnyösnek tekinthető, hogy a jelenlegi krízisszituációban az egyértelmú, lényegre törő és elfogultságtól mentes szakértői kommunikáció különleges jelentőséggel bír: növelheti a fertózéssel kapcsolatos tudatosságot, segít megítélni a tényleges rizikót, és megelőzheti azt, hogy az egyén életében a szükségesnél nagyobb bizonytalanság alakuljon ki $[15,16]$. Ennek megelózése talán az oltással kapcsolatosan bizonytalan csoport esetében a legfontosabb, hiszen eredményeinkből látható, hogy ebben a csoportban döntően középkorú, 37,9\%-ban krónikus beteg emberek vannak, akik sok forrásból keresik az információt, a szakértői kommunikáció pedig enyhülést adhat dilemmáikat illetôen. Az egészségügyi dolgozóknak ilyformán kiemelkedő szerepük van a hozzájuk tanácsért forduló lakosság helyzetének differenciált megértésében, szakértői tájékoztatásában, illetve megfelelő tanácsokkal való ellátásában. Az egészségügyi dolgozók, ha szükséges, el tudják oszlatni a gyógyszercégekkel kapcsolatos kételyeket, az oltás mellékhatásaival kapcsolatos bizonytalanságokat, és ha úgy alakul, meg tudják világítani azokat az előnyöket, illetve hátrányokat, melyekkel az oltás beadatása vagy be nem adása járhat.

Annak ellenére, hogy a védőoltással kapcsolatos kutatások inkább a védőoltás hátrányai mentén körvonalazzák a különböző oltási csoportok közti különbségeket $[3,9]$, vizsgálatunkban azt találtuk, hogy a védőoltás előnyei jóval inkább megkülönböztetik a különböző véleményen lévő embereket. Az oltást választó csoport biztosabb az oltás előnyeiben, az oltást ellenző csoport pedig határozottan nem ért egyet azzal, hogy a vakcinának bármiféle pozitív hozadéka lenne. A csoportok közötti különbség különösen azokban a kérdésekben mutatkozik meg, melyek felhívják a figyelmet arra, hogy a védőoltás közös érdek: a járvány visszaszorítása, a fertőzés terjedésének megakadályozása miatt van rá szükség. Az oltás ezen aspektusának tagadása mögött számos indok állhat (társas izoláció, stresszterheltség vagy traumatizáció), ami további kutatások központi témája lehet. 
Tanulmányunk szempontjából azonban fontos kiemelni, hogy az oltás egyéni hasznával szemben az oltás társadalmi haszna képezi a legnagyobb különbségeket az oltással kapcsolatosan különböző állásponton lévő csoportok között. Ennek a vakcinával kapcsolatos kommunikációban a továbbiakban igen nagy szerepe lehet.
Tanulmányunknak természetesen vannak korlátai, melyek megvitatása nélkül nem lehet teljes az elemzésünk. Mivel vizsgálatunk a koronavírus-járvány időszaka alatt zajlott, döntően online adatfelvételre volt lehetőségünk. Ennek előnye, hogy az anonimitás jobban érvényesül, így a résztvevők a bizalmasabb kérdésekre is szívesebben

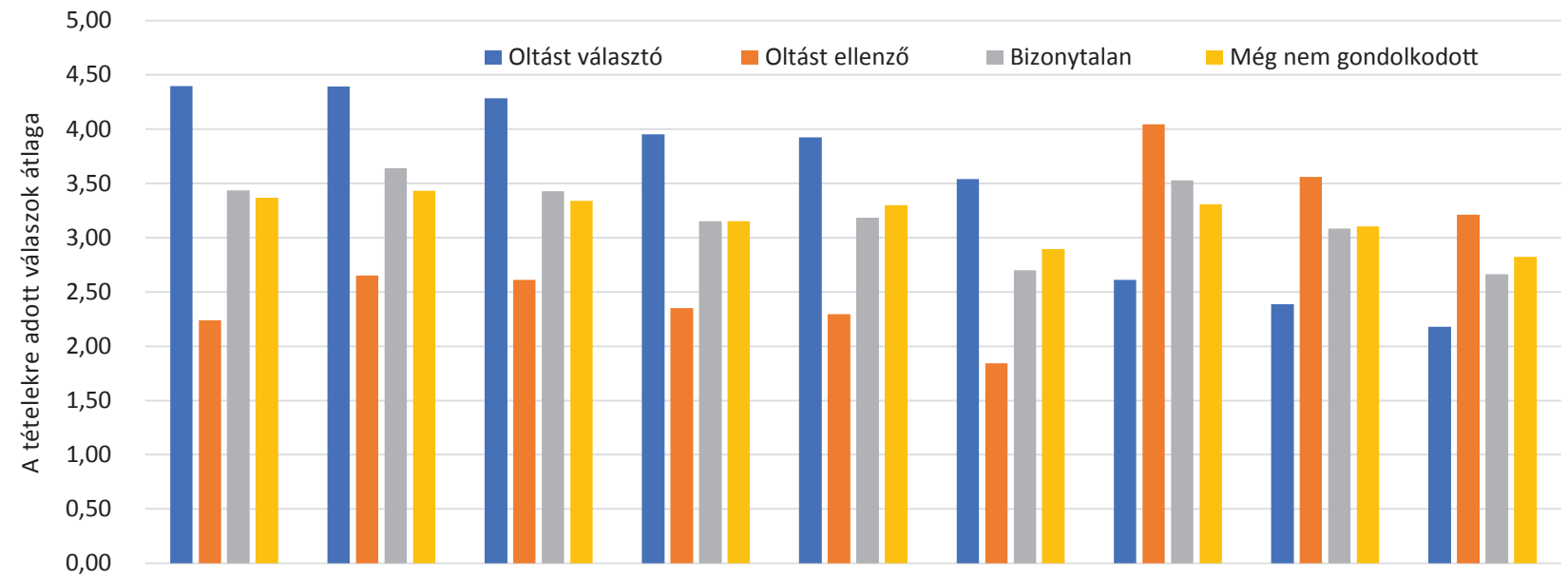

\begin{tabular}{|c|c|c|c|c|c|c|c|c|c|}
\hline & $\begin{array}{l}\text { Megóvja az } \\
\text { egészségem }\end{array}$ & $\begin{array}{l}\text { Hatékony } \\
\text { a járvány } \\
\text { megfékezé- } \\
\text { sére }\end{array}$ & $\begin{array}{l}\text { Ha nem } \\
\text { oltatom } \\
\text { magam, } \\
\text { én fertőzök } \\
\text { másokat }\end{array}$ & $\begin{array}{l}\text { Tesztelik, } \\
\text { mielött } \\
\text { engedélyezik }\end{array}$ & $\begin{array}{l}\text { Megbízom } \\
\text { abban, amit } \\
\text { az orvosok } \\
\text { és járvány- } \\
\text { ügyi } \\
\text { szakértók } \\
\text { mondanak }\end{array}$ & $\begin{array}{l}\text { Az oltásról } \\
\text { kapott } \\
\text { információ } \\
\text { megbízható }\end{array}$ & $\begin{array}{l}\text { Aggódom } \\
\text { a káros } \\
\text { mellékhatá- } \\
\text { sok miatt }\end{array}$ & $\begin{array}{l}\text { A gyógyszer- } \\
\text { cégek elfedik } \\
\text { a védőoltás } \\
\text { veszélyessé- } \\
\text { gét }\end{array}$ & $\begin{array}{l}\text { A káros } \\
\text { mellék- } \\
\text { hatások } \\
\text { felülmúlják } \\
\text { az előnyöket }\end{array}$ \\
\hline Oltást választó & $\begin{array}{l}4,40 \\
(0,69)^{*}\end{array}$ & $\begin{array}{l}4,39 \\
(0,67)\end{array}$ & $\begin{array}{l}4,29 \\
(0,68)\end{array}$ & $\begin{array}{l}3,95 \\
(0,78)\end{array}$ & $\begin{array}{l}3,93 \\
(0,78)\end{array}$ & $\begin{array}{l}3,54 \\
(0,94)\end{array}$ & $\begin{array}{l}2,61 \\
(0,96)\end{array}$ & $\begin{array}{l}2,39 \\
(0,87)\end{array}$ & $\begin{array}{l}2,18 \\
(1,15)\end{array}$ \\
\hline Oltást ellenző & $\begin{array}{l}2,24 \\
(1,00)\end{array}$ & $\begin{array}{l}2,65 \\
(0,96)\end{array}$ & $\begin{array}{l}2,61 \\
(1,00)\end{array}$ & $\begin{array}{l}2,35 \\
(0,90)\end{array}$ & $\begin{array}{l}2,29 \\
(0,90)\end{array}$ & $\begin{array}{l}1,84 \\
(0,84)\end{array}$ & $\begin{array}{l}4,04 \\
(0,97)\end{array}$ & $\begin{array}{l}3,56 \\
(0,99)\end{array}$ & $\begin{array}{l}3,21 \\
(0,97)\end{array}$ \\
\hline Bizonytalan & $\begin{array}{l}3,43 \\
(0,76)\end{array}$ & $\begin{array}{l}3,64 \\
(0,78)\end{array}$ & $\begin{array}{l}3,43 \\
(0,80)\end{array}$ & $\begin{array}{l}3,15 \\
(0,87)\end{array}$ & $\begin{array}{l}3,18 \\
(0,82)\end{array}$ & $\begin{array}{l}2,70 \\
(0,82)\end{array}$ & $\begin{array}{l}3,53 \\
(0,92)\end{array}$ & $\begin{array}{l}3,09 \\
(0,80)\end{array}$ & $\begin{array}{l}2,66 \\
(0,83)\end{array}$ \\
\hline $\begin{array}{l}\text { Még nem } \\
\text { gondolkodott }\end{array}$ & $\begin{array}{l}3,37 \\
(0,73)\end{array}$ & $\begin{array}{l}3,43 \\
(0,78)\end{array}$ & $\begin{array}{l}3,34 \\
(0,78)\end{array}$ & $\begin{array}{l}3,15 \\
(0,82)\end{array}$ & $\begin{array}{l}3,30 \\
(0,82)\end{array}$ & $\begin{array}{l}2,90 \\
(0,91)\end{array}$ & $\begin{array}{l}3,31 \\
(0,94)\end{array}$ & $\begin{array}{l}3,10 \\
(0,78)\end{array}$ & $\begin{array}{l}2,82 \\
(0,70)\end{array}$ \\
\hline $\begin{array}{l}\mathrm{F} \\
\text { (df) } \\
\text { sign. * * }\end{array}$ & $\begin{array}{l}294,27 \\
(3,975) \\
0,00\end{array}$ & $\begin{array}{l}196,00 \\
(3,975) \\
0,00\end{array}$ & $\begin{array}{l}164,92 \\
(3,975) \\
0,00\end{array}$ & $\begin{array}{l}1 \\
(3,975) \\
0,00\end{array}$ & $\begin{array}{l}158,08 \\
(3,975) \\
0,00\end{array}$ & $\begin{array}{l}164,92 \\
(3,975) \\
0,00\end{array}$ & $\begin{array}{l}86,76 \\
(3,975) \\
0,00\end{array}$ & $\begin{array}{l}75,84 \\
(3,975) \\
0,00\end{array}$ & $\begin{array}{l}50,55 \\
(3,975) \\
0,00\end{array}$ \\
\hline \multirow[t]{2}{*}{$\eta^{2 * * *}$} & 0,48 & 0,38 & 0,34 & 0,31 & 0,33 & 0,34 & 0,23 & 0,19 & 0,13 \\
\hline & Előnyök & & & & & & Hátrányok & & \\
\hline Oltást választó & $3,91(0,63)$ & & & & & & $3,91(0,63)$ & & \\
\hline Oltást ellenző & $2,25(0,75)$ & & & & & & $2,25(0,54)$ & & \\
\hline Bizonytalan & $3,14(0,70)$ & & & & & & $3,14(0,64)$ & & \\
\hline $\begin{array}{l}\text { Még nem } \\
\text { gondolkodott }\end{array}$ & $3,18(0,73)$ & & & & & & $3,18(0,53)$ & & \\
\hline $\begin{array}{l}\text { F } \\
\text { (df) } \\
\text { sign. ** }\end{array}$ & $\begin{array}{l}345,47 \\
(3,974) \\
0,00\end{array}$ & & & & & & $\begin{array}{l}128,57 \\
(3,974) \\
0,00\end{array}$ & & \\
\hline$\eta^{2 * * *}$ & 0,52 & & & & & & 0,28 & & \\
\hline
\end{tabular}

*A cellákban az átlag, zárójelben pedig a szórás (SD) található.

**Az F(df)-érték megmutatja az oltási csoportok közti variancia mértékét és a szabadságfokot. A szignifikanciaszint (sign.) pedig a tévedés valószínúségét jellemzi annak kapcsán, hogy hibás következtetést vonunk le a minta vizsgálatából a populációra vonatkozóan.

***Az $\eta^{2}$ (eta-négyzet) megmutatja azt, hogy az oltási csoportok milyen mértékben különböztethetók meg a vizsgált paraméter mentén. Az $\eta^{2}-$ érték százzal való felszorzása százalékban fejezi ki a csoporttagság által megmagyarázott varianciát.

1. ábra $\quad$ Az oltással kapcsolatos vélekedések 


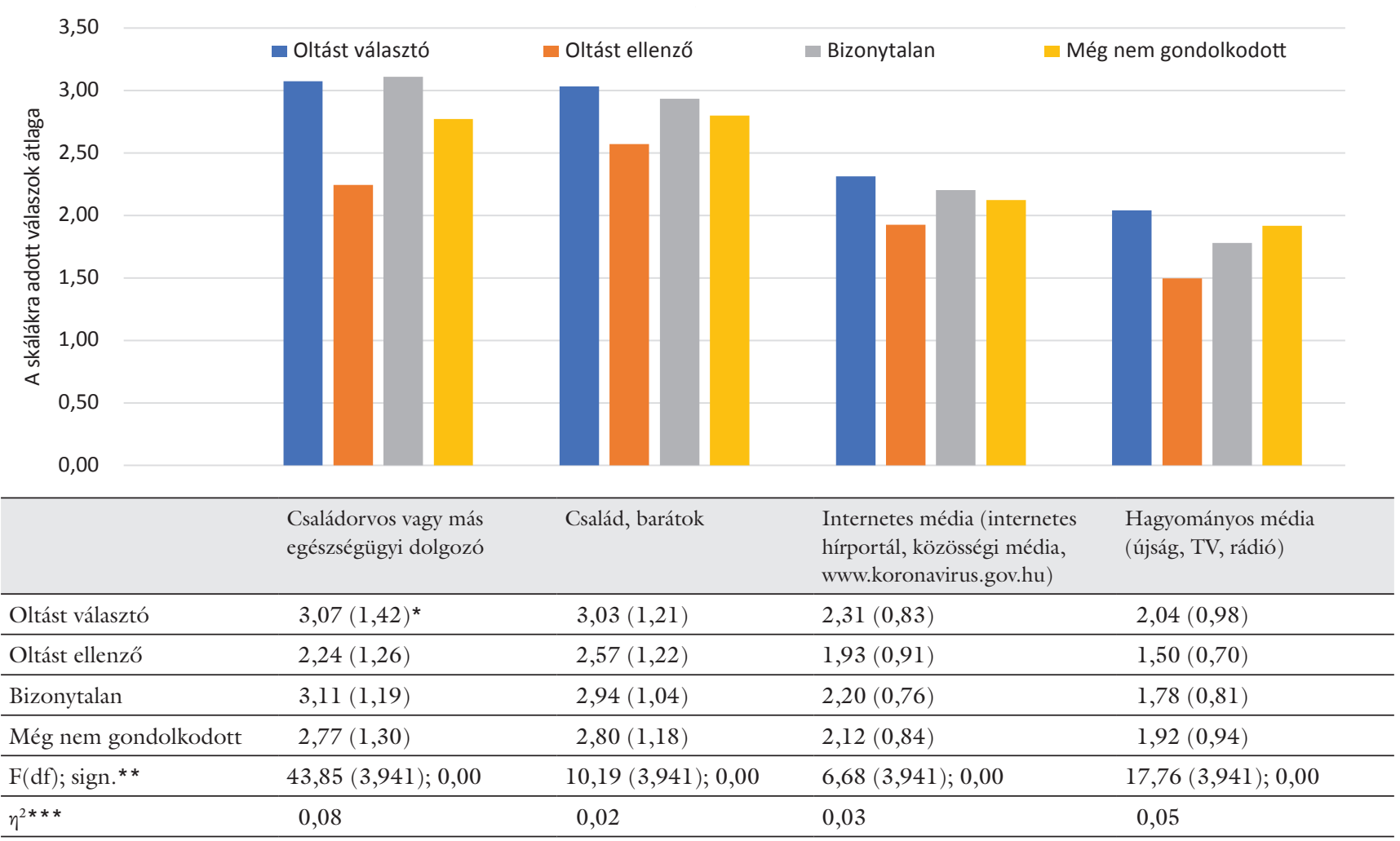

A magyarázat azonos az 1. ábra alatt leírtakkal.

2. ábra | A használt információforrások csoportonként

és őszintébben válaszolnak. Hátránya azonban, hogy szelektálja azokat, akik kevésbé igazodnak el az online eszközök világában. Emellett fontos kiemelni, hogy az általunk vizsgált minta nem volt reprezentatív, ami a következtetések levonását csak korlátozottan teszi lehetővé. Továbbá olyan kérdésekben kértük az emberek véleményét, melyekben álláspontjuk gyorsan változhat, így a 2020 decemberében adott válaszok mindössze egy pillanatképet tudtak rögzíteni. Ezek kompenzálásaképpen döntöttünk úgy, hogy csak a legmarkánsabb különbségeket emeljük ki és fogalmazzuk meg üzenetként. Így elmondható tehát, hogy résztvevóinket az oltás pozitív hozadékai, különösképpen a társadalommal kapcsolatos jelentősége különbözteti meg a leginkább. Emellett kiemelhető, hogy a szakértői tudáson alapuló kommunikáció elengedhetetlen a lakosság oltással kapcsolatos vélekedéseinek formálásában.

Anyagi támogatás: A kutatómunka anyagi támogatását a Károli Gáspár Református Egyetem kutatásfinanszírozási alapja biztosította (Személy- és családorientált egészségtudomány kutatócsoport; pályázati szám: 20643B800).

Szerzői munkamegosztás: M. V.: Statisztikai elemzés, az eredmények interpretációja és szakirodalmi megalapozása, a tanulmány megírása. M. Zs.: Adatgyúijtés, az adatgyújtés koordinációja, az eredmények interpretálása.
K. Zs.: Statisztikai elemzés, az eredmények interpretációja, az adatgyújités koordinációja. A. J.: Adatgyújités, az eredmények interpretációja. V. Z.: Adatgyújtés, az adatgyújtés koordinációja; az eredmények interpretációja. K. P.: Az eredmények interpretációja. R. S.: A kutatás koordinátora, az eredmények interpretációja. A cikk végleges változatát valamennyi szerző elolvasta és jóváhagyta.

Érdekeltségek: A szerzőknek nincsenek érdekeltségeik.

\section{Köszönetnyilvánítás}

A cikk a Károli Gáspár Református Egyetem kutatási finanszírozásának (Személy- és családorientált egészségtudomány kutatócsoport; pályázati szám: 20643B800) köszönhetően készült. Továbbá köszönetünket fejezzük ki a Károli Gáspár Református Egyetem dékánjának, Dr. habil. Horváth Gézának, a támogatásáért és a tanulmány lektorálásáért.

\section{Irodalom}

[1] Szabó Cs, Pukánszky J, Kemény L. Psychological effects of the coronavirus pandemic and their mitigation - review article with opinions from 441 Hungarian adults. [A koronavírusjárványhelyzet pszichológiai hatásai és azok enyhítése - áttekintő közlemény 441 magyar felnőtt véleményével.] Egészségfejlesztés 2020; 61: 30-45. [Hungarian]

[2] Váradi A, Ferenci T, Falus A. The coronavirus-induced COVID-19 pandemic. Previous experiences and scientific evidences at the end of March, 2020. [A koronavírus okozta 
COVID-19-pandémia. Korábbi tapasztalatok és tudományos evidenciák 2020. március végén.] Orv Hetil. 2020; 161: 644651. [Hungarian]

[3] Neumann-Böhme S, Varghese NE, Sabat I, et al. Once we have it, will we use it? A European survey on willingness to be vaccinated against COVID-19. Eur J Health Econ. 2020; 21: 977982.

[4] Marks M, Millat-Martinez P, Ouchi D, et al. Transmission of COVID-19 in 282 clusters in Catalonia, Spain: a cohort study. Lancet Infect Dis. 2021 Feb 2. Doi: 10.1016/S14733099(20)30985-3. [Epub ahead of print]

[5] Osváth P. Psychological outcome of COVID-19 pandemic. How can we prepare for a psychodemic crisis? [A COVID-19-pandémia mentálhigiénés következményei. Hogyan tudunk felkészülni a pszichodémiás krízisre?] Orv Hetil. 2021; 162: 366374. [Hungarian]

[6] Sallam M. COVID-19 vaccine hesitancy worldwide: a concise systematic review of vaccine acceptance rates. Vaccines 2021; 9: 160.

[7] Meier K, Glatz T, Guijt MC, et al. Public perspectives on protective measures during the COVID-19 pandemic in the Netherlands, Germany and Italy: a survey study. PLoS ONE 2020; 15: e0236917.

[8] Hungarian Central Statistical Office. Weekly monitor. HCSO monitor: COVID-19 vaccine. [Központi Statisztikai Hivatal. Heti monitor. KSH felmérés: COVID-19 oltás.] Available from: https://www.ksh.hu/heti-monitor/ [accessed: April 16, 2021]. [Hungarian]

[9] Opinio. Analysis: what do Hungarians think of the vaccine? [Opinio. Elemzés: mit gondolnak a magyarok a vakcináról?] Opinio, January 2021. Available from: https://opinio.hu/ elemzes-mit-gondolnak-a-magyarok-a-vakcinarol/ [accessed: February 7, 2021]. [Hungarian]

[10] Growing willingness to vaccinate in Hungary. [Még tovább nőtt az oltási hajlandóság Magyarországon.] Nézőpont Intézet,
Budapest, 1 March 2021. Available from: https://nezopont. $\mathrm{hu} / \mathrm{meg}$-tovabb-nott-az-oltasi-hajlandosag-magyarorszagon/ [accessed: March 1, 2021]. [Hungarian]

[11] Károli Gáspár University of Reformed Church in Hungary. COVID Research. [Károli Gáspár Református Egyetem. Koronavírus-kutatás.] Károli Gáspár Református Egyetem, April 2020. Available from: http://www.koronaviruskutatas.hu/ eredmenyek/eredmeny-lelkitenyezok/ [accessed: January 20, 2021]. [Hungarian]

[12] Sherman SM, Smith LE, Sim J, et al. COVID-19 vaccination intention in the UK: results from the COVID-19 vaccination acceptability study (CoVAccS), a nationally representative crosssectional survey. Hum Vaccin Immunother. 2020 Nov 26. Doi: 10.1080/21645515.2020.1846397. [Epub ahead of print]

[13] Taylor S, Landry CA, Paluszek MM, et al. A proactive approach for managing COVID-19: the importance of understanding the motivational roots of vaccination hesitancy for SARS-CoV-2. Front Psychol. 2020; 11: 575950.

[14] Charron J, Gautier A, Jestin, C. Influence of information sources on vaccine hesitancy and practices. Med Mal Infect. 2020; 50: 727-733.

[15] Hampel, J. Different concepts of risk - a challenge for risk communication. Int J Med Microbiol. 2006; 296(Suppl 1): 5-10.

[16] Moreno A, Fuentes-Lara C, Navarro C. Covid-19 communication management in Spain: exploring the effect of informationseeking behavior and message reception in public's evaluation. Profesional De La Información 2020; 29(4): e290402. https:// doi.org/10.3145/epi.2020.jul.02

(Mészáros Veronika dr., Budapest, Bécsi út 324., V. ép., 1037 e-mail: meszaros.veronika@kre.hu)

\section{Az Orvosi Hetilap 2021; 162: 728. oldalán (18. szám) megjelent OH-kvízre két helyes megfejtés érkezett. \\ A beküldők: Dr. Bíró László (Budapest) és Dr. Kónya Csaba (Budapest). A nyerteseknek szívből gratulálunk. \\ Nyereményüket - egy, az Akadémiai Kiadó webáruházában kedvezményes vásárlásra jogosító kupont - e-mailen küldjük el.}

A cikk a Creative Commons Attribution 4.0 International License (https://creativecommons.org/licenses/by/4.0/) feltételei szerint publikált Open Access közlemény, melynek szellemében a cikk bármilyen médiumban szabadon felhasználható, megosztható és újraközölhető, feltéve, hogy az eredeti szerző és a közlés helye, illetve a CC License linkje és az esetlegesen végrehajtott módosítások feltüntetésre kerülnek. (SID_1) 